\title{
Penerapan Metode Partisipatorik dalam Meningkatkan Hasil Belajar Bahasa Indonesia Siswa Kelas XI SMA Negeri 9 Gowa
}

\author{
Amal Akbar ${ }^{1}$ \\ Anzar ${ }^{2}$ \\ Suparmin $^{3}$ \\ 12Pendidikan Bahasa dan Sastra Indonesia Fakultas Keguruan dan Ilmu \\ Pendidikan Universitas Muhammadiyah Makassar \\ ${ }^{3}$ SMA Negeri 9 Gowa \\ 19amalakbar@unismuh.ac.id \\ ªnzar@unismuh.ac.id \\ ${ }^{3}$ suparmin@gmail.com
}

\begin{abstract}
Abstrak
Penelitian ini bertujuan untuk mendeskripsikan penerapan metode partisipatorik dalam meningkatkan hasil belajar bahasa Indonesia khususnya menulis paragraf persuasi siswa kelas IX SMA Negeri 9 Gowa pada tahap perencanaan, pelaksanaan, dan penilaian. Penelitian ini merupakan penelitian tindakan kelas yang dilaksanakan dalam bentuk siklus, mulai dari perencanaan, pelaksanaan, observasi, dan refleksi. Subjek penelitian ini adalah guru dan siswa IX SMA Negeri 9 Gowa dengan jumlah siswa 36 orang. Teknik pengumpulan data yang digunakan adalah observasi, wawancara, catatan lapangan, dan analisis tes uraian dan tes kemampuan menulis paragraf persuasi sebagai instrumen penelitian pada tiap siklus untuk mengumpulkan data yang diperlukan. Hasil penelitian membuktikan bahwa penerapan metode partisipatorik dapat meningkatkan hasil belajar menulis paragraf persuasi pada siswa IX SMA Negeri 9 Gowa. Hasil penelitian menunjukkan bahwa tes uraian menulis paragraf persuasi yang dilakukan secara individu pada siklus I mencapai 67,13\%, sedangkan pada siklus II mencapai 85,43\%. Jadi, jumlah peningkatannya mencapai $18,3 \%$. Adapun pada tes kemampuan menulis paragraf persuasi yang dilakukan secara berkelompok pada siklus I mencapai 69,45\%, sedangkan pada siklus II mencapai 76,16\%. Jadi, jumlah peningkatannya mencapai 6,71\%. Berdasarkan hasil penelitian ini dapat disimpulkan bahwa penerapan metode partisipatorik dapat meningkatkan pembelajaran menulis paragraf persuasi siswa IX SMA Negeri 9 Gowa.
\end{abstract}

Kata kunci: partisipatorik, paragraf persuasi

\section{Pendahuluan}

Kualitas hasil belajar siswa sangat ditentukan oleh proses pembelajaran. Kualitas dan proses pembelajaran tersebut merupakan amanah UU. No. 20 tahun 2003 tentang sistem pendiikan Nasional bab I pasal I menyebutkan bahwa: "Pendidikan adalah usaha sadar dan terencana untuk mewujudkan suasana belajar dan proses pembelajaran agar peserta didik secara aktif mengembangkan potensi dirinya untuk memiliki kekuatan spiritual ke Agamaan, pengendalian diri, kepribadian, kecerdasan, akhlak mulia, serta 
keterampilan yang diperlukan dirinya, masyarakat, bangsa, dan negara" (Undang-Undang RI No. 20 Tahun 2003 Tentang Sistem Pendidikan Nasional, 2007). Untuk mewujudkan hal tersebut, dibutuhkan pemilihan metode pembejaran. Setidaknya, ada tujuh metode mengajar bahasa yang dikatagorikan metode yang sudah lama, yaitu: (1) Grammar Translation Method, (2) Direct Method, (3) Audio-Lingual Method, (4) Silent Way, (5) Suggestopedia, (6) Total Physical Response, dan (7) Communicative Language Teaching (Larsen \& Freeman D., 1986). Berdasarkan hasil observasi yang dilakukan oleh peneliti, terhadap beberapa mahasiswa yang melaksanakan Program Magang 3 atau praktik mengajar, masih banyak sekolah yang tidak memperhatikan pemilihan dan penggunaan metode pembelajaran dalam setiap proses pembelajaran.

Hasil observasi awal di SMA Negeri 9 Gowa ditemukan bahwa hasil belajar Bahasa Indonesia masih rendah disebabkan karena empat faktor penting yaitu: (1) Dominasi guru dalam proses pembelajaran membuat siswa merasa jenuh menjalani pembelajaran; (2 Guru tidak menerapkan metode atau model pembelajaran secara variatif, (3) Guru tidak menunjukkan usaha solutif untuk mengatasi masalah-masalah yang terjadi selama proses pembelajaran.

Hasil observasi tersebut juga menunjukkan hasil belajar siswa masih berada di bawah Kriteria Ketuntasan Minimal (KKM) di SMA NEGERI 9 GOWA yaitu 70, sedangkan siswa dikatakan tuntas belajar jika skor rata-rata yang diperoleh minimal $85 \%$ dari jumlah siswa telah tuntas secara klasikal.

Berdasarkan kenyataan tersebut, penulis melakukan penelitian yang berjudul "Penerapan Metode Partisipatorik Dalam Meningkatkan Hasil Belajar Bahasa Indonesia Siswa Kelas XI SMA Negeri 9 Gowa". Penelitian ini, dilakukan dengan maksud untuk meningkatkan hasil belajar siswa kelas XI SMA Negeri 9 Gowa dalam menulis karangan persuasi. Penggunaan metode pembelajaran partisipatorik sekaligus untuk mengetahui sejauh mana konsep pengajaran bahasa yang diterapkan di sekolah tersebut.

Hal tersebut dilakukan agar pembelajaran biasanya hanya disampaikan dengan menggunakan metode ceramah yang memusatkan proses belajar pada guru, sehingga guru berperan aktif sedaangkan siswa cenderung pasif. Siswa yang cepat menguasai materi pelajaran kurang bisa berbagi dengan temannya yang sulit menerima materi pelajaran, sehingga sulit terjadi kerjasama dalam hal berbagi ilmu pengetahuan. Hal ini sangat berpengaruh terhadap prestasi belajar di sekolah. Oleh karena itu, diperlukan inovasi dalam kegiatan proses pembelajaran untuk mengatasi permasalahan tersebut. Berdasarkan hal tersebut, penelitian ini menggunakan konsep pembelajaran Partisipatorik sebagai upaya solutif untuk mengatasi berbagai permasalahan tersebut.

\section{Kerangka Teori}

Pembelajaran partisipatorik merupakan pembelajaran yang berpusat pada kegiatan peserta didik, bukan pada pengajar. Model pembelajaran menekankan pada peran aktif peserta didik (learning by doing) secara bersama-sama untuk menemukan dan membangun pengetahuan yang menjadi tujuan pembelajaran. Ciri pembelajaran tersebut adalah (1) proses pembelajaran terjadi dalam komunikasi dua arah (timbal balik) antara pengajar dengan peserta didik; (2) terjadi aksi dan reaksi antara kedua belah pihak; (3) kedua belah pihak secara aktif saling merespons selama proses pembelajaran (Maksum \& Purwanto, 2019).

Metode pembelajaran partisipatori merupakan metode pembelajaran memiliki keleluasaan yang sangat besar terhadap siswa dalam mengembangkan kemampuannya baik dalam menemukan masalah, mencari informasi, dan merekonstruksi informasi 
sehingga dapat digunakan untuk menyelesaikan masalah. Ciri khas metode pembelajaran ini adalah student centered yang artinya siswa atau peserta didik memiliki kebutuhan belajar, memahami teknik-teknik belajar, dan berperilaku belajar. Tugas guru dalam metode pembelajaran ini adalah untuk mengarahkan siswa serta menjadi fasilitator dan mediator bagi siswa pada saat siswa mengalami kesulitan dalam merekonstruksi informasi. Dalam metodepembelajaran ini, guru harus menguasai metode dan Teknik pembelajaran, memahami materi, berperilaku membelajarkan anak didik (Kariasih, 2021).

Metodepembelajaran tersebut akan diterapkan pada pembelajaran bahasa Indonesia. Pembelajaran bahasa Indonesia terdiri atas beberap komponen pembelajaran yang memberikan keleluasaan kepada pengajar untuk memilih salah satu kompenen yang terdiri atas komponen kebahasaan, pemahaman, dan penggunaan. Pembelajaran bahasa Indonesia adalah pembelajaran yang diajarkan disekolah sejak sekolah dasar hingga perguruan tinggi yang meliputi kompenon-komponen kebahasaan, pemahaman, dan penggunaan (Yuhandika, dkk., 2021).

Komponen kebahasaan mencakup empat aspek keterampilan berbahasa, yaitu mendengarkan, berbicara, membaca, dan menulis. Aspek-aspek keterampilan tersebut menuntut peserta didik untuk berfikir lebih kritis, terfokus, dan terarah sehingga dapat meningkatkan keterampilan berbahasa peserta didik (Dinda, 2021; Monica Cristina Febrianti, 2021; Suciati Fitria Suryani, 2021).

Meskipun terdapat empat aspek keterampilan berbahasa, akan tetapi penelitian ini difokuskan pada aspek keterampilan menulis. Menulis merupakan keterampilan berkomunikasi dalam rangka mengekspresikan gagasan secara produktif menggunakan ragam bahasa tulis (Maulyda, dkk., 2020; Robles \& Torres, 2020; Telaumbanua, 2020).

Selanjutnya, secara spesifik penelitian ini difokuskan pada keterampilan menulis karangan persuasi. Keterampilan menulis karangan persuasi adalah keterampilan menuangkan gagasan menggunakan ragam tulis yang bertujuan agar penulis dapat memengaruhi pembaca agar mengikuti kehendak penulis (León Lúa, 2020; Vinh dkk., 2020).

\section{Metode}

Jenis peneitian yang digunakan pada penelitian ini adalah jenis Penelitian Tindakan Kelas. Penelitian Tindakan Kelas (PTK) atau Classroom Action Research (CAR) merupakan penelitian Tindakan yang dilaksanakan di dalam kelas Ketika pembelajaran berlangsung. PTK dilakukan dengan tujuan memperbaiki atau meningkatkan kualitas pembelajaran. PTK berfokus pada kelas atau pada proses pembelajaran yang terjadi di dalam kelas (Saputra dkk., 2021, hlm. 1).

Penelitian Tindakan Kelas ini direncanakan dalam bentui siklus penelitian. Siklus penelitai meliputi beberapa tahapan, yaitu perencanaan tindakan, pelaksanaan tindakan, pengamatan, dan penilaian serta refleksi. Jika pada siklus pertama belum berhasil, maka akan dilanjutkan pada siklus berikutnya (siklus ke-n).

Penelitian ini dilaksanakan di SMA 9 Gowa dan subjek penelitian dalam penelitian ini adalah siswa kelas IX1. Adapun wujud data pada penelitian meliputi data proses dan produk. Data proses dilakukan dengan cara mengobservasi kegiatan siswa selama mengikuti pembelajaran dari tahap pramenulis, menulis, dan publikasi. Sedangkan data produk berupa hasil tulisan mengenai menulis paragraf persuasi setelah mengikuti proses pembelajaran menulis paragraf melalui metodepembelajaran partisipatorik. 
Teknik pengumpulan data yang digunakan dalam penelitian ini adalah observasi, wawancara, catatan lapangan, dan teknik teks unjuk kerja (latihan). Data yang terkumpul berupa data hasil observasi, wawancara, dan catatan lapangan tentang proses pembelajaran menulis paragraf persuasi dengan menggunakan metode partisipatorik, serta hasil tulisan siswa. Data tersebut direduksi berdasarkan masalah yang diteliti, diikuti penyajian data, dan terakhir penyimpulan atau verifikasi.

\section{Hasil}

Ada enam aspek yang dinilai pada tes kemampuan menulis paragraf persuasi secara berkelompok, yaitu (1) kohesi, (2) koherensi, (3) penggunaan ejaan yang disempurnakan, (4) penggunaan bahasa, (5) diksi (pilihan kata), dan (6) kerapian. Hasil analisis tes kemampuan menulis paragraf persuasi secara kelompok pada siklus pertama ditunjukkan dalam tabel 1 berikut.

Tabel 1 Hasil Tes Kemampuan Menulis Paragraf Persuasi dengan Metode Partisipatorik

\begin{tabular}{|c|c|c|c|c|c|c|c|c|}
\hline \multirow{2}{*}{ No. } & \multirow{2}{*}{ Nama Kelompok } & \multicolumn{6}{|c|}{ Aspek yang Dinilai } & \multirow{2}{*}{ Nilai } \\
\hline & & 1 & 2 & 3 & 4 & 5 & 6 & \\
\hline 1. & $\begin{array}{c}\text { Kelompok } 1 \\
003,006,026\end{array}$ & 11,5 & 13,5 & 6,5 & 12,5 & 28,5 & 5 & 77,5 \\
\hline 2. & $\begin{array}{c}\text { Kelompok 2 } \\
014,016,011\end{array}$ & 13 & 11 & 7,5 & 7,5 & 15 & 4 & 58 \\
\hline 3. & $\begin{array}{c}\text { Kelompok } 3 \\
005,029,023\end{array}$ & 12,5 & 14 & 9,5 & 13 & 26 & 5 & 80 \\
\hline 4. & $\begin{array}{c}\text { Kelompok } 4 \\
004,017,019\end{array}$ & 9 & 14,5 & 7 & 6,5 & 13 & 5 & 55 \\
\hline 5. & $\begin{array}{c}\text { Kelompok } 5 \\
033,009,027\end{array}$ & 12 & 13 & 7,5 & 12,5 & 14,5 & 5 & 64,5 \\
\hline 6. & $\begin{array}{c}\text { Kelompok } 6 \\
034,007,013\end{array}$ & 12,5 & 15 & 7,5 & 7 & 24 & 5 & 71 \\
\hline 7. & $\begin{array}{c}\text { Kelompok } 7 \\
008,012,032\end{array}$ & 13,5 & 11 & 8,5 & 13 & 25 & 4 & 75 \\
\hline 8. & $\begin{array}{c}\text { Kelompok } 8 \\
022,025,036\end{array}$ & 13,5 & 13 & 7,5 & 13,5 & 11,5 & 5 & 64 \\
\hline 9. & $\begin{array}{c}\text { Kelompok } 9 \\
001,002,020\end{array}$ & 12,5 & 14 & 7,5 & 12 & 10,5 & 5 & 61,5 \\
\hline 10. & $\begin{array}{l}\text { Kelompok } 10 \\
010,031,015\end{array}$ & 13,5 & 15 & 7,5 & 11,5 & 28,5 & 5 & 81 \\
\hline 11. & $\begin{array}{l}\text { Kelompok } 11 \\
021,024,028\end{array}$ & 12,5 & 15 & 6,5 & 6,5 & 18,5 & 5 & 64 \\
\hline 12. & $\begin{array}{c}\text { Kelompok } 12 \\
018,035,030\end{array}$ & 14,5 & 15 & 7 & 12,5 & 28 & 5 & 82 \\
\hline & Jumlah & 150,5 & 164 & 90 & 128 & 243 & 58 & 833,5 \\
\hline & Rata-rata & 12,54 & 13,66 & 7,5 & 10,66 & 20,25 & 4,83 & 69,45 \\
\hline
\end{tabular}

Berdasarkan hasil penilaian kemampuan menulis paragraf persuasi yang dilakukan secara berkelompok, dari dua belas kelompok yang terbentuk enam kelompok di antara mendapat nilai $<70$, sedangkan enam kelompok lainnya mendapat nilai $>70$. Adapun kelompok yang mendapatkan nilai tertinggi yaitu kelompok 12 dengan nilai 82, sedangkan kelompok yang mendapatkan nilai terendah yaitu kelompok 4 dengan nilai 55. Dengan demikian, dapat disimpulkan bahwa penggunaan metode partisipatorik dalam menulis paragraf persuasi pada siklus pertama belum berhasil dan akan dilakukan perbaikan pada siklus berikutnya atau siklus kedua. 
Adapun hasil observasi yang dilakukan selama proses pembelajaran menulis paragraf persuasi dengan menggunakan metode partisipatorik pada siklus pertama pertemuan pertama dapat diketahui bahwa 36 siswa atau $100 \%$ menyimak kompetensi dasar dan tujuan pembelajaran yang disampaikan oleh guru. Adapun pada saat guru menyampaikan penjelasan tentang materi paragraf persuasi dan memberikan pertanyaan kepada siswa mengenai materi yang telah disampaikan ada 26 siswa atau $72 \%$ yang aktif. Jadi, dapat disimpulkan 10 siswa atau $27 \%$ kurang mendengarkan penjelasan guru tentang materi pembelajaran menulis paragraf persuasi dan kurang dapat menjawab pertanyaan yang diberikan oleh guru.

Adapun hasil analisis tes kemampuan menulis paragraf persuasi pada siklus kedua ditunjukkan dalam tabel 2 berikut:

Tabel 2 Hasil Tes Kemampuan Menulis Paragraf Persuasi dengan Metode Partisipatorik

\begin{tabular}{|c|c|c|c|c|c|c|c|c|}
\hline \multirow{2}{*}{ No. } & \multirow{2}{*}{ Nama Kelompok } & \multicolumn{6}{|c|}{ Aspek yang Dinilai } & \multirow{2}{*}{ Nilai } \\
\hline & & 1 & 2 & 3 & 4 & 5 & 6 & \\
\hline 1. & $\begin{array}{c}\text { Kelompok } 1 \\
003,006,026\end{array}$ & 11,5 & 13 & 7,5 & 12 & 30 & 5 & 79 \\
\hline 2. & $\begin{array}{c}\text { Kelompok } 2 \\
014,016,011\end{array}$ & 12 & 12,5 & 9,5 & 11,5 & 27,5 & 5 & 78 \\
\hline 3. & $\begin{array}{c}\text { Kelompok } 3 \\
005,029,023\end{array}$ & 12,5 & 15 & 8,5 & 13,5 & 30 & 5 & 84,5 \\
\hline 4. & $\begin{array}{c}\text { Kelompok } 4 \\
004,017,019\end{array}$ & 13 & 13 & 8,5 & 13 & 24,5 & 5 & 77 \\
\hline 5. & $\begin{array}{c}\text { Kelompok } 5 \\
033,009,027\end{array}$ & 13 & 13 & 7,5 & 12 & 22,5 & 5 & 73 \\
\hline 6. & $\begin{array}{c}\text { Kelompok } 6 \\
034,007,013\end{array}$ & 12 & 12,5 & 8,5 & 11,5 & 29 & 5 & 78,5 \\
\hline 7. & $\begin{array}{c}\text { Kelompok } 7 \\
008,012,032\end{array}$ & 12 & 12,5 & 7 & 12,5 & 25,5 & 5 & 74,5 \\
\hline 8. & $\begin{array}{c}\text { Kelompok } 8 \\
022,025,036\end{array}$ & 12 & 11,5 & 9 & 13 & 30 & 5 & 80,5 \\
\hline 9. & $\begin{array}{c}\text { Kelompok } 9 \\
001,002,020\end{array}$ & 12 & 15 & 7,5 & 13 & 10 & 5 & 62,5 \\
\hline 10. & $\begin{array}{c}\text { Kelompok } 10 \\
010,031,015\end{array}$ & 11,5 & 13 & 7,5 & 13 & 29 & 5 & 79 \\
\hline 11. & $\begin{array}{l}\text { Kelompok } 11 \\
\text { 021, 024, } 028\end{array}$ & 11,5 & 13 & 7 & 13 & 26 & 5 & 75,5 \\
\hline 12. & $\begin{array}{l}\text { Kelompok } 12 \\
018,035,030\end{array}$ & 13 & 14 & 7,5 & 12,5 & 20 & 5 & 72 \\
\hline & Jumlah & 146 & 158 & 95,5 & 150,5 & 304 & 60 & 914 \\
\hline & Rata-rata & 12,16 & 13,16 & 7,95 & 12,54 & 25,33 & 5 & 76,16 \\
\hline
\end{tabular}

Berdasarkan hasil penilaian kemampuan menulis paragraf persuasi yang dilakukan secara berkelompok, dari dua belas kelompok yang terbentuk sebelas kelompok di antara mendapat nilai $>70$, sedangkan satu kelompok mendapat nilai $<70$. Adapun kelompok yang mendapatkan nilai tertinggi yaitu kelompok 3 dengan nilai 84,5, sedangkan kelompok yang mendapatkan nilai terendah yaitu kelompok 9 dengan nilai 62,5 . Dengan demikian, dapat disimpulkan bahwa penggunaan metode partisipatorik dalam menulis paragraf persuasi pada siklus kedua dinyatakan berhasil.

Hasil observasi yang dilakukan pada siklus kedua berjalan lancar. Hal ini tergambar pada kesiapan siswa pada saat mengikuti proses pembelajaran. Siswa yang pada saat siklus pertama pasif dalam menjawab, mengemukakan pendapat, dan bertanya bila mengalami kesulitan akhirnya menjadi aktif pada siklus kedua. 
Berdasarkan pemaparan hasil penelitian tersebut, penerapan metode partisipatorik dapat meningkatkan pembelajaran menulis paragraf persuasi. Metode partisipatorik membantu siswa untuk memproses informasi yang sudah tersedia dalam benaknya siswa dan menyusun pengetahuan mereka sendiri tentang dunia sosial dan sekitarnya Ratumanan (dalam Trianto, 2011, hlm. 92). Selain itu, penggunaan metode partisipatorik dalam pembelajaran menulis paragraf persuasi dimaksudkan sebagai alat untuk memudahkan siswa dalam menuangkan ide, pikiran, perhatian, dan kemauan menulis siswa. Hal ini sesuai dengan yang dikemukakan oleh Maksum dan Purwanto bahwa Pembelajaran partisipatorik merupakan pembelajaran yang berpusat pada kegiatan peserta didik, bukan pada pengajar. Metode pembelajaran menekankan pada peran aktif peserta didik (learning by doing) secara bersama-sama untuk menemukan dan membangun pengetahuan yang menjadi tujuan pembelajaran. Ciri pembelajaran tersebut adalah (1) proses pembelajaran terjadi dalam komunikasi dua arah (timbal balik) antara pengajar dengan peserta didik; (2) terjadi aksi dan reaksi antara kedua belah pihak; (3) kedua belah pihak secara aktif saling merespons selama proses pembelajaran (Maksum \& Purwanto, 2019).

Penelitian tindakan ini dilakukan dalam dua siklus. Pada proses perencanaan siklus pertama dan kedua, pembelajaran menulis paragraf persuasi dengan menggunakan metode partisipatorik menunjukkan bahwa perencanaan pembelajaran disusun dan dirancang secara rinci dan spesifik. Setiap perencanaan pembelajaran membahas hal-hal yang akan dilakukan dalam bentuk RPP. Perencanaan pembelajaran yang mencakup halhal yang dikerjakan secara sistematis dengan kebutuhan dan tujuan pembelajaran dalam menulis.

Dalam proses pelaksanaan pembelajaran pada siklus pertama dan siklus kedua, guru berkolaborasi dengan peneliti menjalankan penelitian ini dengan menggunakan metode partisipatorik dalam pembelajaran menulis paragraf persuasi. Pada siklus pertama, pertemuan pertama, guru menyampaikan materi pembelajaran yang akan diajarkan yaitu menulis gagasan dalam bentuk paragraf persuasi. Penekanan pembelajaran pada pertemuan pertama ini adalah kemampuan awal siswa mengenai pengertian paragraf persuasi, ciri-ciri paragraf persuasi, dan cara penulisan paragraf persuasi dengan memerhatikan keterpaduan kalimat (kohesi), keterkaitan makna (koherensi), penggunaan PUEBI, penggunaan bahasa, dan diksi (pilihan kata) yang bersifat membujuk atau meyakinkan pembaca agar melakukan apa yang diinginkan oleh penulis.

Berdasarkan perencanaan penelitian yang telah ditetapkan pada pertemuan kedua, materi pembelajaran yang diajarkan adalah menulis paragraf persuasi dengan menggunakan metode partisipatorik dengan memerhatikan keterpaduan kalimat (kohesi), keterkaitan makna (koherensi), penggunaan PUEBI, penggunaan bahasa, diksi (pilihan kata) yang bersifat membujuk atau meyakinkan pembaca agar melakukan apa yang diinginkan penulis, dan kerapian. Akan tetapi sebelum itu, guru membahas terlebih dahulu soal tertulis yang diberikan kepada siswa secara individu pada pertemuan sebelumnya.

Pertemuan selanjutnya diadakan selama 2 jam pelajaran ( $2 \times 45$ menit). Pada pertemuan kali ini, masing-masing kelompok mengolah data-data atau informasi yang telah mereka dapatkan ke dalam bentuk paragraf persuasi. Setelah itu, salah satu siswa dari perwakilan kelompok membacakan hasil menulis paragraf persuasi di depan kelas. Setelah paragraf tersebut dibacakan, siswa dari kelompok yang lain menanggapi hasil tulisan paragraf persuasi yang dibuat oleh kelompok tersebut. Diskusi ini dipandu oleh 
guru mata pelajaran. Kegiatan selanjutnya yaitu siswa mengumpulkan hasil tes menulis paragraf persuasi yang dikerjakan secara berkelompok.

Karena siklus pertama tidak berhasil maka dilanjutkan ke siklus kedua dengan langkah-langkah pembelajaran seperti siklus pertama, tetapi terlebih dahulu harus dilakukan refleksi terhadap proses pembelajaran yang telah dilakukan. Pada tahap siklus pertama ketuntasan belajar siswa mencapai 67,13 dan ketuntasan belajar siswa pada siklus kedua mencapai 85,43. Adapun pada tes kemampuan menulis paragraf persuasi yang dilakukan secara berkelompok dengan memerhatikan kohesi, koherensi, penggunaan PUEBI, penggunaan bahasa, diksi (pilihan kata), dan kerapian menunjukkan bahwa pada tahap siklus pertama ketuntasan belajar siswa mencapai 69,45 dan ketuntasan belajar siswa pada siklus kedua mencapai 76,16.

\section{Simpulan}

Berdasarkan penyajian hasil analisis data dan pembahasan, kesimpulan yang dapat diperoleh adalah pembelajaran siswa dalam menulis paragraf persuasi siswa kelas IX 1 SMA Negeri 9 Gowa mengalami peningkatan setelah penerapan metode partisipatorik.

Perencanaan pembelajaran menulis paragraf persuasi dengan menggunakan metode partisipatorik pada siswa kelas kelas IX ${ }_{1}$ SMA Negeri 9 Gowa dirancang secara berkolaborasi guru dan peneliti dalam bentuk RPP yang memuat standar kompetensi, kompetensi dasar, indikator, tujuan pembelajaran, materi pembelajaran, bahan, alat, media, sumber belajar, dan penilaian. Pelaksanaan pembelajaran menulis paragraf persuasi dengan menggunakan metode partisipatorik pada siswa kelas kelas IX $\mathrm{IMA}_{1}$ Negeri 9 Gowa dilaksanakan selama dua siklus dengan dua kali pertemuan setiap siklus.

Pada tahap penilaian, menunjukkan bahwa hasil tes uraian menulis paragraf persuasi yang dilakukan secara individu siswa kelas IX 1 SMA Negeri 9 Gowa menunjukkan bahwa pada tahap siklus pertama ketuntasan belajar siswa mencapai 67,13 dan ketuntasan belajar siswa pada siklus kedua mencapai 85,43. Adapun pada tes kemampuan menulis paragraf persuasi yang dilakukan secara berkelompok dengan memerhatikan kohesi, koherensi, penggunaan PUEBI, penggunaan bahasa, diksi (pilihan kata), dan kerapian menunjukkan bahwa pada tahap siklus pertama ketuntasan belajar siswa mencapai 69,45 dan ketuntasan belajar siswa pada siklus kedua mencapai 76,16.

\section{Ucapan Terima Kasih}

\section{Daftar Pustaka}

Dinda, A. A. (2021). Pelaksanaan Layanan Bimbingan Belajar untuk Meningkatkan Keterampilan Belajar Peserta Didik Kelas X di SMA Pangudi Luhur Bandar Lampung Tahun Ajaran 2019/2020 [UIN Raden Intan Lampung]. http://repository.radenintan.ac.id/13418/

Kariasih, N. L. P. (2021). Model Pembelajaran Partisipatori Berbantuan Teknik Know Want Learn (KWL) Sebagai Upaya untuk Meningkatkan Motivasi dan Prestasi Belajar Agama Hindu dan Budi Pekerti. Jurnal Inovasi, 7(5), 10-16.

Larsen, \& Freeman D. (1986). Techniques and Principles in Language Teaching. Oxford University Press. 
León Lúa, G. Q. (2020). The influence of modal verbs in the writing skill [B.S. thesis]. Universidad de Guayaquil. Facultad de Filosofía, Letras y Ciencias de la ....

Maksum, H., \& Purwanto, W. (2019). Model Pembelajaran Pendidikan Vokasi Otomotif (PVO). UNP PRESS.

Maulyda, M. A., Annizar, A. M., Hidayati, V. R., \& Mukhlis, M. (2020). Analysis of students' verbal and written mathematical communication error in solving word problem. Journal of Physics: Conference Series, 1538, 012083. https://doi.org/10.1088/1742-6596/1538/1/012083

Monica Cristina Febrianti, 165030042. (2021). Analisis Struktur Puisi "Masih Ingatkah Kau Jalan Pulang" Karya Sapardi Djoko Damono dan Rintik Sedu sebagai Bahan Ajar Bahasa Indonesia Kelas $X$ SMA [FKIP UNPAS]. https://doi.org/10/Ringkesan.pdf

Robles, R. M. V., \& Torres, J. M. (2020). Filipino ESL teachers' attitudes, practices and challenges in using peer correction strategy in teaching writing. Ciencia (HEALS), 1(1), 1-26.

Saputra, N., Zanthy, L. S., Gardini, E., Jahring, Rif'an, A., \& Arifin, A. (2021). Penelitian Tindakan Kelas. Yayasan Penerbit Muhammad Zaini.

Suciati Fitria Suryani, 165030003. (2021). Analsis Gaya Bahasa pada Kumpulan Puisi "Mawar Merah" Karya Chalik Hamid sebagai Alternatif Pemilihan Bahan Ajar Apresiasi Sastra Indonesia di SMA [FKIP UNPAS]. https://doi.org/10/Bab\%20V.pdf

Telaumbanua, T. (2020). Student's Diffucultie In Writing Narrative Text at The Ninth Grade Students of SMP Swasta Kristen BNKP Teluk Dalam. Jurnal Education and Development, 8(1), 464-464.

Trianto. (2011). Mendesain Model Pembelajaran Inovatif-Progresif. Kencana.

Undang-Undang RI No. 20 Tahun 2003 Tentang Sistem Pendidikan Nasional. (2007). Visi Media.

Vinh, T., Thomas, D., \& Thomas, A. (2020). Writing persuasive texts: Using grammatical metaphors for rhetorical purposes in an educational context. Australian Journal of Linguistics, 40(2), 139-159.

Yuhandika, T., Nursalim, \& Fitri, A. (2021). Pengembangan Rencana Pelaksanaan Pembelajaran (RPP) Bahasa Indonesia dalam Kurikulum 2013. Jurnal Pentas: Jurnal Ilmiah Pendidikan Bahasa dan Sastra Indonesia, 7(1), 74-82. 